Materiales de Construcción

Vol. 66, Issue 321, January-March 2016, e077

ISSN-L: 0465-2746

http://dx.doi.org/10.3989/mc.2016.03615

\title{
Natural pozzolan-and granulated blast furnace slag-based binary geopolymers
}

\author{
R.A. Robayo ${ }^{\mathrm{a}}$, R. Mejía de Gutiérrez $₫$, M. Gordillo ${ }^{\mathrm{b}}$ \\ a. Universidad del Valle (Cali, Colombia) \\ b. Universidad Autónoma de Occidente (Cali, Colombia) \\ $\triangle$ ruby.mejia@correounivalle.edu.co
}

\author{
Received 14 may 2015 \\ Accepted 25 august 2015 \\ Available on line 19 january 2016
}

\begin{abstract}
This study describes the synthesis at ambient temperature $\left(25 \pm 3{ }^{\circ} \mathrm{C}\right)$ of binary geopolymer systems based on natural volcanic pozzolan and granulated blast furnace slag. $\mathrm{Na}_{2} \mathrm{SiO}_{3}$ and $\mathrm{NaOH}$ were used as alkaline activators. The effects of the $\mathrm{SiO}_{2} / \mathrm{Al}_{2} \mathrm{O}_{3}, \mathrm{Na}_{2} \mathrm{O} / \mathrm{Al}_{2} \mathrm{O}_{3}$ ratio and the amount of slag added (from 0 to $30 \%$ ) on the reaction kinetics, compressive strength and microstructure of the final product were studied. To characterise the geopolymer pastes, techniques such as X-ray diffraction (XRD), infrared spectroscopy (FTIR) and scanning electron microscopy (SEM) were used. The results indicate the possibility of obtaining a geopolymer cement with a compressive strength of up to $48.11 \mathrm{MPa}$ after 28 days of curing at ambient temperature whose characteristics are comparable to those of commercial portland cement.
\end{abstract}

KEYWORDS: Alkaline-activated cement; Volcanic Pozzolan; Blast furnace slag; Compressive Strength; Characterization

Citation/Citar como: Robayo, R.A.; Mejía de Gutiérrez, R.; Gordillo, M. (2016) Natural pozzolan- and granulated blast furnace slag-based binary geopolymers. Mater. Construcc. 66 [321], e077. http://dx.doi.org/10.3989/mc.2016.03615.

RESUMEN: Geopolímeros de tipo binario basados en una puzolana natural y escoria siderúrgica de alto horno. Este trabajo describe la síntesis a temperatura ambiente $\left(25 \pm 3{ }^{\circ} \mathrm{C}\right)$ de sistemas geopoliméricos de tipo binario basados en una puzolana natural de origen volcánico y escoria siderúrgica de alto horno usando activadores alcalinos basados en la combinación de $\mathrm{Na}_{2} \mathrm{SiO}_{3}$ y NaOH . Se estudió el efecto de la relación $\mathrm{SiO}_{2} / \mathrm{Al}_{2} \mathrm{O}_{3}, \mathrm{Na}_{2} \mathrm{O} /$ $\mathrm{Al}_{2} \mathrm{O}_{3}$ y la cantidad de escoria adicionada en niveles entre el 0 y $30 \%$ sobre la cinética de reacción, la resistencia a la compresión y la microestructura del producto final. Para la caracterización de las pastas geopoliméricas se utilizaron técnicas como difracción de rayos X (DRX), espectroscopia infrarroja (FTIR) y microscopia electrónica de barrido (MEB). Los resultados conseguidos revelan la posibilidad de obtener un cementante geopolimérico con una resistencia a la compresión de hasta 48,11 MPa a los 28 días de curado a temperatura ambiente cuyas características son comparables a las de un cemento portland comercial.

PALABRAS ClAVE: Cemento activado alcalinamente; Puzolana volcánica; Escoria Siderúrgica de alto horno; Resistencia a la Compresión; Caracterización

Copyright: (C) 2016 CSIC. This is an open-access article distributed under the terms of the Creative Commons Attribution-Non Commercial (by-nc) Spain 3.0 License.

\section{INTRODUCTION}

Geopolymers are a group of cementing ceramic materials belonging to the family of inorganic polymers that are obtained from the reaction between an aluminosilicate (primary precursor) and one alkaline activator. These materials have been widely developed and have gradually attracted the attention of the scientific and industrial world as revolutionary materials. This attention is partly due to their technical and environmental advantages, the ease of implementing new technologies for their production and the 
versatility of their application to different engineering fields. Despite the excellent properties obtained from the activation of industrial by-products and waste as precursors, the nature of these materials leads to variability in their chemical and mineral compositions, which makes it more difficult to standardise an activation process to obtain specific mechanical and durability properties. These challenges have incentivised the development of studies focused on the production of alkaline activation cements based on different natural resources, such as clays (particularly kaolinites and smectites) and natural pozzolans, which could be a more viable alternative from a commercial standpoint when adopting these materials on an industrial scale.

In particular, the use of natural volcanic pozzolans in geopolymer synthesis is a subject of great interest and economic significance for countries that possess large deposits of these materials, such as Colombia. This type of material could be advantageous as an alternative cementing agent to replace portland cement in certain applications and contribute positively to reducing the environmental impact of its production (1-6). It is worth noting that approximately $0.84 \%$ of soils from tropical regions of the world are composed of volcanic ashes, and in Colombia they occupy approximately $11.6 \%$ of the national territory. In Colombia, volcanic ashes are located in areas of higher demographic and economic growth, particularly throughout the entire Andes region and in the centre and southern part of Colombia (7).

Lemougna et al. (8), Tchakoute et al. (9), Bondar et al. (10), and Kani and Allahverdi (11), among others, have used volcanic pozzolans from different sources as precursors in the production of geopolymer cements with satisfactory results. Tchakoute et al. (9) report compressive strength of up to $50 \mathrm{MPa}$ after 28 days of curing at ambient temperature for a volcanic pozzolan from Cameroon. However, other researchers have noted the need for thermal curing treatments or the addition of secondary $\mathrm{CaO}$ and $\mathrm{Al}_{2} \mathrm{O}_{3}$ sources such as granulated blast furnace slag (GBFS) and metakaolin (MK) to achieve good mechanical performance in a short amount of time due to the semi-crystalline nature and the deficiencies in the reactivity of $\mathrm{CaO}$ and $\mathrm{Al}_{2} \mathrm{O}_{3}$ in these materials (10, 12-14). According to Rodríguez et al. (15) and Li et al. (16), the addition of GBFS as a source of $\mathrm{Ca}^{2+}$ cations allows the curing and hardening of alkaline activation blends at ambient temperature, which contributes to the formation of calcium silicate hydrate gels $(\mathrm{C}-\mathrm{S}-\mathrm{H})$ and hydrated calcium silicoaluminates (C-A-S-H) $(6,17)$.

Allahverdi et al. (13) obtained a binary geopolymer with natural Iranian pozzolan (Taftan) and the addition of $5 \%$ of GBFS with a compressive strength of $36 \mathrm{MPa}$ after 28 days of curing at ambient temperature using as the activator, a blend of $\mathrm{Na}_{2} \mathrm{SiO}_{3}$ and $\mathrm{NaOH}$ with a $\mathrm{SiO}_{2} / \mathrm{Na}_{2} \mathrm{O}$ ratio of 0.6 and liquid/solid ratio of 0.3 . From the same precursor, a hybrid cement based on $25 \%$ of portland cement and $75 \%$ pozzolan was produced, which had a strength of $33 \mathrm{MPa}$. However, after 360 days, the strength increased to $61.4 \mathrm{MPa}$ (18). In general, in both studies, the researchers reported the need to adequately control the quantity of sodium oxide present in the blend to avoid the formation of efflorescence. Kani et al. (19) analysed two methods to avoid such efflorescences: the addition of materials rich in alumina (metakaolin and calcium aluminate cements) to the system and hydrothermal curing at $65^{\circ} \mathrm{C}$; in both cases, the methods proved to be efficient.

The purpose of this study is to determine the optimal synthesis parameters at ambient temperature $\left(25 \pm 3{ }^{\circ} \mathrm{C}\right), \mathrm{SiO}_{2} / \mathrm{Al}_{2} \mathrm{O}_{3}$ molar ratio and GBFS (percentage) of a binary-type geopolymer system in natural pozzolan of volcanic origin and granulated blast furnace slag. The setting time, heat of reaction, compressive strength and the microstructure were evaluated.

\section{MATERIAL AND METHODS}

\subsection{Materials}

As raw materials for the production of the geopolymer material, Colombian natural pozzolan (NP) of volcanic origin and granulated blast furnace slag (GBFS) were used. The chemical composition of these materials, which are shown in Table 1, was determined by X-ray fluorescence (XRF) using a MagiX-Pro PW-2440 Phillips spectrometer equipped with a rhodium tube with maximum power of $4 \mathrm{KW}$. $\mathrm{NP}$ is known for its high $\mathrm{SiO}_{2} / \mathrm{Al}_{2} \mathrm{O}_{3}$ (6.28) molar ratio and low content of the alkaline components, $\mathrm{CaO}, \mathrm{Na}_{2} \mathrm{O}$ and $\mathrm{K}_{2} \mathrm{O}$.

Figure 1 shows the X-ray diffraction pattern obtained for the natural pozzolan (NP), where several common minerals can be identified, such as quartz $\left(\mathrm{SiO}_{2}\right)$, anorthite $\left(\mathrm{Ca}\left(\mathrm{Al}_{2} \mathrm{Si}_{2} \mathrm{O}_{8}\right)\right)$, cordierite $\left(\mathrm{Mg}_{2}\left(\mathrm{Al}_{4} \mathrm{Si}_{5} \mathrm{O}_{18}\right)\right)$ and montmorillonite $(\mathrm{Na}, \mathrm{Ca})_{0,3}$ $(\mathrm{Al}, \mathrm{Mg})_{2}\left(\mathrm{Si}_{4} \mathrm{O}_{10}(\mathrm{OH})_{2 \mathrm{X}} \mathrm{H}_{2} \mathrm{O}\right)$ plagioclases. The latter, part of the smectite family of the phyllosilicate mineral group, exhibited the highest water adsorption among the clay minerals due to its laminar structure and the charge distribution patterns inside its structure (20). To reduce the demand of water in the geopolymer material, it was necessary to calcine the material at $700{ }^{\circ} \mathrm{C}$, which was performed at a heating rate of $14^{\circ} \mathrm{C} / \mathrm{min}$ and maintained for 15 minutes. Then, the calcined material was left to cool in the oven to $400{ }^{\circ} \mathrm{C}$ and then removed and allowed to cool to room temperature. The effect of this treatment is reflected in the XRD patterns, which indicate a remarkable reduction of the wide, high-intensity peak located at a $2 \theta$ value of $5.7^{\circ}$, which corresponds 
TABLE 1. Chemical composition of the raw materials (Mass \% as oxides) (LOI is loss on ignition at $1000{ }^{\circ} \mathrm{C}$ )

\begin{tabular}{|c|c|c|c|c|c|c|c|c|c|c|c|}
\hline Material & $\mathrm{SiO}_{2}$ & $\mathbf{A l}_{2} \mathbf{O}_{3}$ & $\mathrm{Fe}_{2} \mathrm{O}_{3}$ & $\mathrm{CaO}$ & $\mathrm{Na}_{2} \mathrm{O}$ & MgO & $\mathbf{K}_{2} \mathbf{O}$ & $\mathrm{TiO}_{2}$ & $\mathrm{MnO}$ & LOI & $\begin{array}{l}\text { Molar ratio } \\
\mathrm{SiO}_{2} / \mathrm{Al}_{2} \mathrm{O}_{3} \\
\end{array}$ \\
\hline NP & 61.17 & 16.57 & 5.81 & 2.86 & 0.66 & 3.73 & 0.68 & 0.52 & 0.16 & 7.63 & 6.28 \\
\hline $\mathrm{NP}\left(700^{\circ} \mathrm{C}\right)$ & 64.53 & 16.93 & 6.03 & 3.02 & 1.12 & 3.59 & 0.62 & 0.55 & 0.1 & 3.32 & 6.48 \\
\hline GBFS & 37.74 & 15.69 & 1.85 & 40.3 & 0.2 & 1.3 & 0.4 & 0.5 & 1.61 & - & 4.09 \\
\hline
\end{tabular}

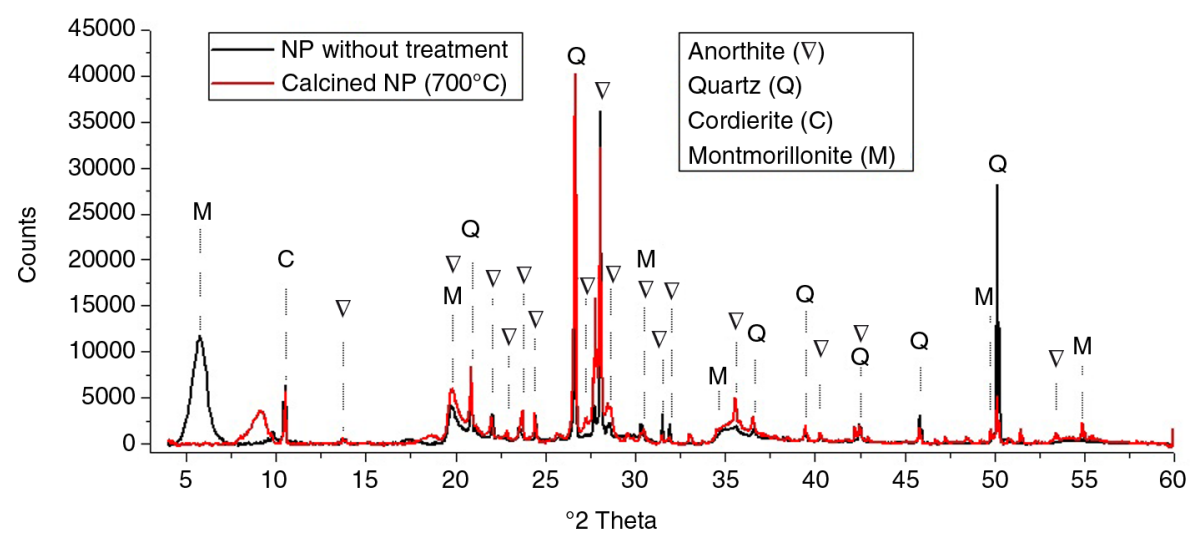

FIGURE 1. X-Ray diffractogram of the NP before and after thermal treatment.

to the montmorillonite phase (Figure 1). The chemical composition of $\mathrm{NP}\left(700{ }^{\circ} \mathrm{C}\right)$ can be observed in Table 1.

The X-ray diffraction pattern of the GBFS is shown in Figure 2, which indicates that the slag is primarily vitreous because of the halo located in the range between $2 \theta$ values of 23 and $37^{\circ}$. This region also indicates signals corresponding to gehlenite $\left(2 \mathrm{CaOAl}_{2} \mathrm{O}_{3} \mathrm{SiO}_{2}\right)$ and calcite $\left(\mathrm{CaCO}_{3}\right)$.

The particle size analysis was performed by laser granulometry using a Mastersizer 2000 instrument from Malvern Instruments coupled to a Hydro 2000 MU dispersion unit; distilled water was used as the dispersing medium. The average particle sizes $\mathrm{D}[4 ; 3]$ obtained for the $\mathrm{NP}\left(700^{\circ} \mathrm{C}\right)$ and GBFS were $17.73 \mu \mathrm{m}$ and $26.44 \mu \mathrm{m}$, respectively.

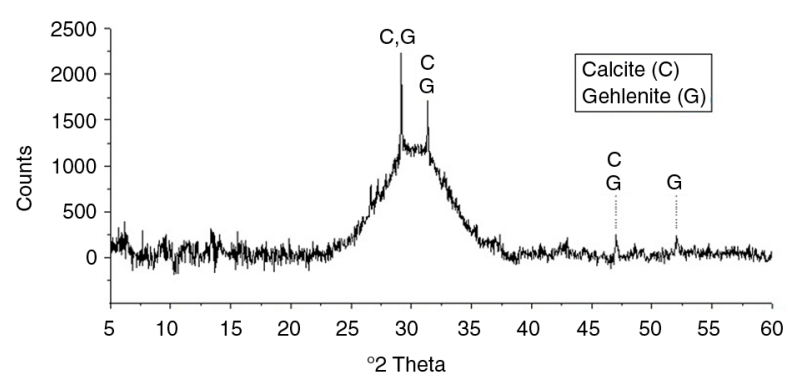

FIgURE 2. X-Ray diffractogram of the GBFS.

\subsection{Experimental design}

For the statistical analysis of the information obtained in the study, a design of response-surface methodology was outlined and executed. As study factors, the molar ratio $\mathrm{SiO}_{2} / \mathrm{Al}_{2} \mathrm{O}_{3}$ and the GBFS \% of the blend were evaluated, each of which was divided into three levels to generate ten treatments (Table 2). Each of these treatments was randomly performed under equivalent conditions. The response variable in the statistical analysis was the compressive strength after 7 and 28 days of curing at ambient temperature.

TABle 2. Composition of the blends

\begin{tabular}{lcccc}
\hline Blend & $\begin{array}{c}\mathrm{SiO}_{2} / \mathbf{A l}_{2} \mathbf{O}_{3} \\
(\mathbf{M o l a r})\end{array}$ & $\begin{array}{c}\mathbf{N a}_{2} \mathbf{O} / \mathbf{A l}_{2} \mathbf{O}_{3} \\
\text { (Molar) }\end{array}$ & $\begin{array}{c}\mathbf{L} / \mathbf{S} \\
\text { Ratio }\end{array}$ & $\begin{array}{c}\% \\
\text { GBFS }\end{array}$ \\
\hline GP1 & 7.5 & 0.6 & 0.35 & 0 \\
GP2 & 6.5 & 0.6 & 0.35 & 10 \\
GP3 & 7.0 & 0.6 & 0.35 & 10 \\
GP4 & 7.5 & 0.6 & 0.32 & 10 \\
GP5 & 6.5 & 0.6 & 0.32 & 20 \\
GP6 & 7.0 & 0.6 & 0.32 & 20 \\
GP7 & 7.5 & 0.6 & 0.32 & 20 \\
GP8 & 6.5 & 0.6 & 0.32 & 30 \\
GP9 & 7.0 & 0.6 & 0.32 & 30 \\
GP10 & 7.5 & 0.6 & 0.32 & 30 \\
\hline & & & &
\end{tabular}


The analysis of the resulting data and the contour graphs were performed in the MINITAB statistical package version 15. Simultaneously, the significance of the interaction and the primary effects of each factor on the response variable were evaluated. The equation that expresses the linear surface response model is given by Equation [1]:

$Y=\beta_{0}+\beta_{1} X_{1}+\beta_{2} X_{2}+\beta_{3} X_{1}^{2}+\beta_{4} X_{2}^{2}+\beta_{5} X_{1} X_{2}+\varepsilon$

Where $Y$ is the compressive strength response variable; $\beta_{(s)}$ are the model coefficients determined by the least squares method; $X_{1}$ is the quantity of GBFS; $X_{2}$ is the $\mathrm{SiO}_{2} / \mathrm{Al}_{2} \mathrm{O}_{3}$ ratio; $X_{1} X_{2}$ is the effect of interaction and $\varepsilon_{i}$ is the experimental error.

\subsection{Preparation of blends and experimental techniques}

The geopolymer pastes were obtained from a Hobart mixer with a mixing time of 10 minutes using the dosages shown in Table 2, which indicates that the liquid/solid ratio (L/S) were 0.32 and 0.35 to ensure easy handling. The pastes in their fresh state were moulded into $20 \mathrm{~mm}$ cubes and vibrated for 30 seconds on an electric vibration table to remove trapped air. Then, the moulds were covered with polyethylene film, which allowed control of the evaporation of free water in the blend, and they were then cured at ambient temperature $\left(25 \pm 3{ }^{\circ} \mathrm{C}\right)$ for 24 hours. Once this period had passed, the samples were removed from their moulds and taken to a curing chamber to ensure a relative humidity greater than $90 \%$ was reached until the test age. The setting time was determined according to the procedure described in the ASTM C191 (method B) standard. The heat of reaction and heating rate were evaluated by an isothermal I-Cal 8000 (Calmetrix) calorimeter at $25{ }^{\circ} \mathrm{C}$. The compressive strength was evaluated after 7 and 28 days of curing in an INSTRON 3369 universal test machine with a $50 \mathrm{kN}$ capacity and deformation rate of $1 \mathrm{~mm} / \mathrm{min}$. In each case, a minimum of three specimens was used.

For the microstructural study of each blend, different instrumental techniques were used, such as the following:

- X-Ray diffraction using X X'Pert-MRD diffractometer from PanAnalytical with $\mathrm{Cu}$ a radiation and a rate of 0.020 for the $2 \theta$ range between 5 and $60^{\circ}$.

- Fourier transform infrared spectroscopy using an R-100 spectrometer from Perkin Elmer in transmittance mode with a frequency between 4000 and $450 \mathrm{~cm}^{-1}$. The samples were evaluated using the compressed $\mathrm{KBr}$ pellet methodology.

- Scanning electron microscopy using a JSM 6490LV JOEL electron microscope with an acceleration voltage of $20 \mathrm{kV}$. The samples were evaluated in low-vacuum mode with a Link-Isis $\mathrm{X}$-ray spectrometer from Oxford Instruments coupled to the microscope.

\section{RESULTS AND DISCUSSION}

\subsection{Statistical modelling}

To model the effect of the $\mathrm{SiO}_{2} / \mathrm{Al}_{2} \mathrm{O}_{3}$ molar ratio and the $\%$ of GBFS, a linear model is proposed that satisfies the error assumptions of the model ( $p$-value $>8.6 \%$ ). Using the least squares methods (Table 3 ), estimates of the regression coefficients (Coef.) were obtained, which showed that the linear effects and both the quadratic and interaction terms are significant at a the 0.000 level in the proposed model.

Table 4 shows the analysis of variance to verify the suitability of the linear model (degrees of freedom, d.f.; sum-of-squares, SS; Mean square, MS; F-ratio, F; p-value, P). At a significance level of 0.376 , the null hypothesis was not rejected. In relation to the significance of the linear, quadratic and interaction effects, they are not significant at a level of 0.000 within the proposed model.

With this model, a multiple determination coefficient $\mathrm{R}^{2}$ value of $93.55 \%$ was obtained, which is the measurement of the variation in compressive strength (Y) associated with the factors of the GBFS (\%) and $\mathrm{SiO}_{2} / \mathrm{Al}_{2} \mathrm{O}_{3}$ ratio [Equation 2].

$$
\begin{aligned}
Y= & -2008.640+15.371 X_{1}+555.460 X_{2}-0.056 X_{1}^{2} \\
& -38.141 X_{2}^{2}-1.822 X_{1} X_{2}+\varepsilon
\end{aligned}
$$

TABle 3. Coefficients of the model

\begin{tabular}{lrrrc}
\hline Term & \multicolumn{1}{c}{ Coef. } & SE Coef. & \multicolumn{1}{c}{ T } & P \\
\hline Constant & -2008.640 & 340.104 & -5.906 & 0.000 \\
\% of GBFS & 15.372 & 1.547 & 9.937 & 0.000 \\
$\mathrm{SiO}_{2} / \mathrm{Al}_{2} \mathrm{O}_{3}$ ratio & 555.460 & 97.522 & 5.696 & 0.000 \\
$(\% \text { of } \mathrm{GBFS})^{2}$ & -0.056 & 0.008 & -7.025 & 0.000 \\
$\left(\mathrm{SiO}_{2} / \mathrm{Al}_{2} \mathrm{O}_{3} \text { ratio }\right)^{2}$ & -38.141 & 6.969 & -5.473 & 0.000 \\
\% of $\mathrm{GBFS}^{*} \mathrm{SiO}_{2} / \mathrm{Al}_{2} \mathrm{O}_{3}$ ratio & -1.822 & 0.194 & -9.396 & 0.000 \\
\hline
\end{tabular}

TABLE 4. Analysis of variances of the model

\begin{tabular}{lrrrcc}
\hline Source & d.f. & \multicolumn{1}{c}{ SS } & MS & F & P \\
\hline Regression & 5 & 3155.32 & 631.06 & 55.11 & 0.000 \\
Linear & 2 & 1603.21 & 770.98 & 67.33 & 0.000 \\
Quadratic & 2 & 541.25 & 487.08 & 42.54 & 0.000 \\
Interaction & 1 & 1010.85 & 1010.85 & 88.28 & 0.000 \\
Residual error & 19 & 217.56 & 11.45 & - & - \\
Lack of fit & 4 & 50.71 & 12.68 & 1.14 & 0.376 \\
Pure error & 15 & 166.85 & 11.12 & - & - \\
Total & 24 & 3372.88 & - & - & - \\
\hline
\end{tabular}




\subsection{Compressive strength}

Figure 3 correspond to the contour graphs obtained in Minitab, which demonstrate the compressive strength of the geopolymer systems as a function of the $\mathrm{SiO}_{2} / \mathrm{Al}_{2} \mathrm{O}_{3}$ ratio and the \% of GBFS present in the blends after 7 and 28 days of curing (Table 2). As one can see, the compressive strength increased proportionally to the quantity of GBFS, reaching a strength of up to $48.11 \mathrm{MPa}$ after 28 days of curing at ambient temperature $\left(25^{\circ} \mathrm{C}\right)$ when the $\mathrm{SiO}_{2} / \mathrm{Al}_{2} \mathrm{O}_{3}$ ratio and GBFS \% were 6.5 and $30 \%$, respectively. If this value is compared with that reported for the simple system (NP) after 28 days of curing (12.96 MPa), the increase is $73 \%$, which confirms that the reaction kinetics are positively affected by the addition of GBFS to the system and agrees with the results reported by other researchers $(6,13,16,21)$.

This mechanical behaviour can be attributed to the higher reactivity of GBFS, which in the presence of the alkaline activator $\left(\mathrm{OH}^{-}\right)$, promotes the rupture of bonds in its structure (Ca-O; Si-O and Al-O) that generates dissolved species $\left(\mathrm{Ca}^{2+} ; \mathrm{H}_{2} \mathrm{SiO}_{4}\right]^{2-}$, $\left[\mathrm{H}_{3} \mathrm{SiO}_{4}\right]^{-}$and $\left.\left[\mathrm{Al}(\mathrm{OH})_{4}\right]^{-}\right)$, that can precipitate when supersaturation is reached forming C-A-S-H hydrate (15). In turn, the calcium present in GBFS becomes part of the Si-O-Al gel structure, which compensates for the charge of the aluminium atoms $\left(\mathrm{Al}^{3+}\right)$ and allows space for the C-A-S-H system in addition to the N-A-S-H gel. This contributes to the formation of a denser, stronger structure $(6,9,13,14,22,23)$.

\subsection{Geopolymerisation kinetics}

The kinetics of the geopolymerisation reactions of the simple and binary systems $\left(\mathrm{SiO}_{2} / \mathrm{Al}_{2} \mathrm{O}_{3}\right.$ molar ratios of 7.5 and 6.75 , respectively) were studied via isothermal calorimetry (Figure 4). The heating rate curve for the binary systems indicates a wider peak of higher intensity in comparison to the simple system; this increase is related to the GBFS percentage present in the blend. As a consequence of this behaviour, the total heat of reaction increased from $34.34 \mathrm{~J} / \mathrm{g}$ of binder in the simple system (NP) to $83.52 \mathrm{~J} / \mathrm{g}$ of binder when $30 \%$ of GBFS is included, as observed in Table 5. This value is comparable to that reported for GBFS 48 hours after activation with silicate and sodium hydroxide (24). From the results, it can be deduced that the presence of $\mathrm{CaO}$ as a consequence of the addition of GBFS generated an increase in the reaction heat. Thus, this phenomenon contributes to the formation of more stable and stronger structures compared with simple systems as a result of the simultaneous formation of
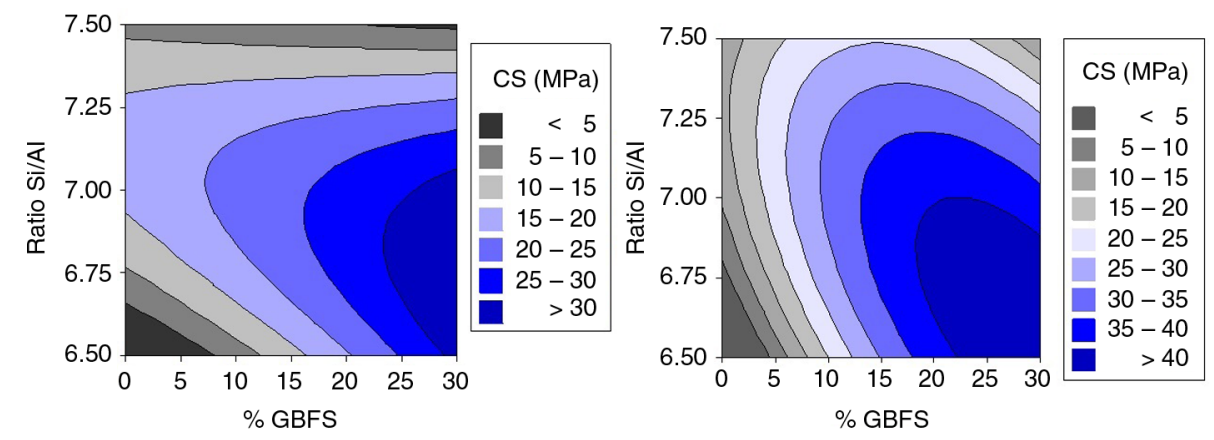

Figure 3. Contour lines of compressive strength (CS) as a function of the $\mathrm{SiO}_{2} / \mathrm{Al}_{2} \mathrm{O}_{3}$ ratio and $\%$ of GBFS (Left; 7 days of curing) (Right; 28 days of curing).
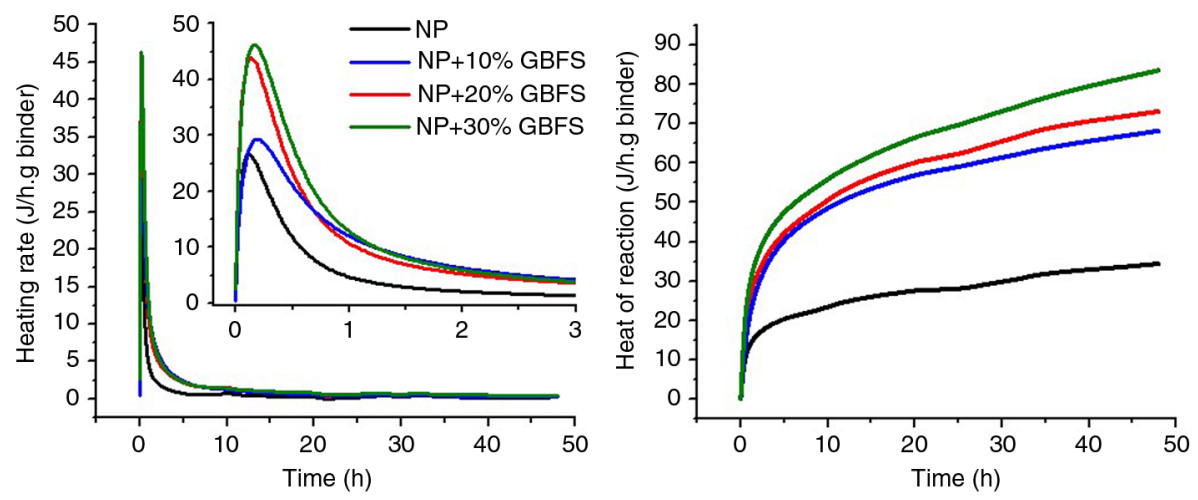

FIGURE 4. Curves of heating rate and total heat of reaction for the alkaline-activated systems. 
TABLE 5. Total heat of reaction and initial and final curing times of the blends

\begin{tabular}{lccc}
\hline Blend & $\begin{array}{c}\text { Initial setting } \\
\text { time (min) }\end{array}$ & $\begin{array}{c}\text { Final setting } \\
\text { time (min) }\end{array}$ & $\begin{array}{c}\text { Heat of reaction } \\
\text { (J/g of binder) }\end{array}$ \\
\hline $\mathrm{NP}$ & 829 & 851 & 34.34 \\
$\mathrm{NP}+10 \% \mathrm{GBFS}$ & 135 & 144 & 68.11 \\
$\mathrm{NP}+20 \% \mathrm{GBFS}$ & 109 & 133 & 73.05 \\
$\mathrm{NP}+30 \% \mathrm{GBFS}$ & 100 & 111 & 83.52 \\
\hline
\end{tabular}

the geopolymeric network and C-S-H gel. This finding correlates with the highest mechanical strengths that have been attained by binary blends $(8,25-28)$.

The setting times of the different geopolymer samples, which are considered an indicator of the kinetics of the geopolymerisation reactions (23), are shown in Table 5, which shows evidence that the incorporation of GBFS and its proportion in binary systems $(\mathrm{NP}+\mathrm{GBFS})$ reduces the initial and final setting times of the simple system (NP). This result, in turn, helps to corroborate the acceleration effect of the geopolymerisation reactions. The final setting time of the simple system (NP) is 851 minutes, which is reduced by $87 \%$ by adding $30 \%$ GBFS (Table 5 ). These results agree with the increase of the heat of reaction of the binary samples and with the results found by other researchers $(9,11,13)$. This effect of adding GBFS to geopolymer systems has been attributed to the simultaneous formation of C-S-H and C-A-S-H gels that together with the N-A-S-H gel, form the C-(N)-AS-H- gel $(6,15,16)$.

The addition of GBFS to NP could, in practice, furnish the activation energy required to expedite geopolymerisation of the natural pozzolan studied, ruling out the need for thermal curing requirements.

\subsection{Microstructural characteristics}

Figure 5a shows the X-ray diffraction pattern obtained for the simple (NP) and binary (NP+GBFS) geopolymer systems with $\mathrm{SiO}_{2} / \mathrm{Al}_{2} \mathrm{O}_{3}$ molar ratios of 7.5 and 6.75 , respectively. Several minerals, present in the natural pozzolan used as a precursor (NP), are identified such as quartz, plagioclases $\left(\mathrm{Ca}\left(\mathrm{Al}_{2} \mathrm{Si}_{2} \mathrm{O}_{8}\right)\right.$, $\left.\mathrm{Mg}_{2}\left(\mathrm{Al}_{4} \mathrm{Si}_{5} \mathrm{O}_{18}\right)\right)$ and montmorillonite, which confirms its minimum participation in the geopolymerisation process. The intensity of the crystalline peaks is notably reduced in the binary systems (NP+GBFS).

The Fourier transform infrared spectroscopy analyses of the simple (NP) and binary (NP+GBFS) blends corroborate the presence of montmorillonite and quartz, and several of their bands are superposed with the Si-O bands present in montmorillonite (Figure $5 \mathrm{~b}$ ). The principal band centred at $1032 \mathrm{~cm}^{-1}$ is attributed to the vibration by stretching of the bonds in $\mathrm{SiO}_{4}$ tetrahedrons (montmorillonite, Si-O stretching). The amplitude of this peak and the formation of the peaks detected at lower $\left(\sim 1010 \mathrm{~cm}^{-1}\right)$ and higher frequencies $\left(\sim 1110 \mathrm{~cm}^{-1}\right)$ can be related to different types of vibrations caused by the low symmetry of the tetrahedrons. The signal detected at $915 \mathrm{~cm}^{-1}$ corresponds to the flexural vibration of $\mathrm{Al}-\mathrm{OH}$ bonds. The high-intensity peak identified at $522 \mathrm{~cm}^{-1}$ for the simple blends corresponds to the vibrations from stretching the Si-O-Al bonds, which suggests that $\mathrm{Al}$ is present in tetrahedral sheets. Notably, this signal had decreased intensity in the binary systems, suggesting that the addition of GBFS promotes the dissolution of certain phases rich in $\mathrm{SiO}_{2}$ and $\mathrm{Al}_{2} \mathrm{O}_{3}$ that are present in NP. The band at around $460 \mathrm{~cm}^{-1}$ is attributed to $\mathrm{Si}-\mathrm{O}-\mathrm{Si}$ bond vibrations (29). The signals identified at $\sim 915$, $\sim 1040$ and $\sim 3630 \mathrm{~cm}^{-1}$ are attributed to octahedral $\mathrm{Al}$ species. The intense band located at $1644 \mathrm{~cm}^{-1}$ is characteristic of the vibrations due to deformation of the bonds in the water molecules present in montmorillonite. The signal detected at $3631 \mathrm{~cm}^{-1}$ along with a higher intensity at $3440 \mathrm{~cm}^{-1}$ corresponds to the vibrations by stretching of the -OH bonds of the water molecules and the vibrations by stretching of the Al-OH bonds of montmorillonite, which shows a high concentration of $\mathrm{Al}$ at octahedral sites. The signals at 694,779 and $796 \mathrm{~cm}^{-1}$ can be associated with quartz. In particular, for the case of binary systems, a band was identified between 1428 and $1482 \mathrm{~cm}^{-1}$,

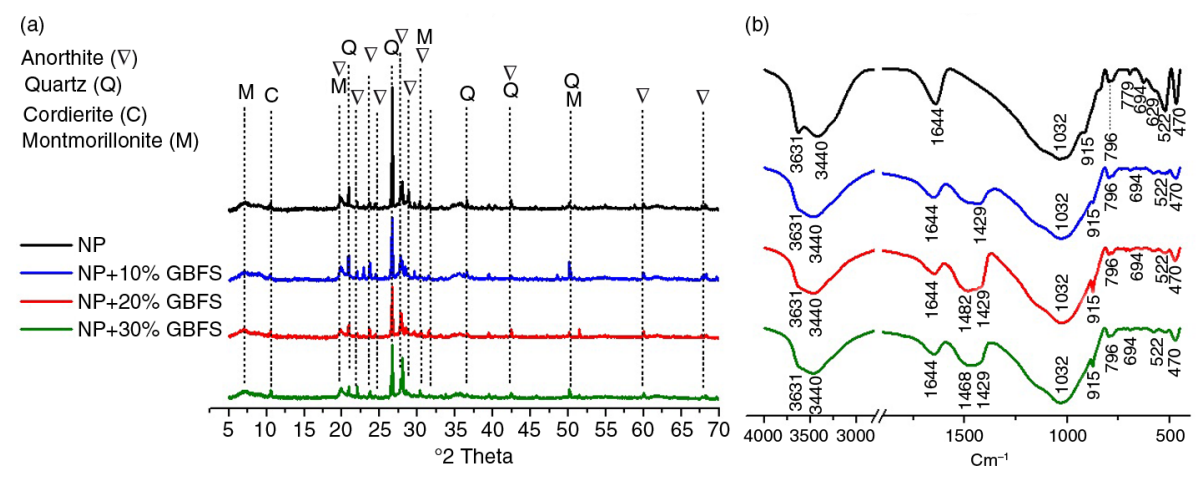

FIGURE 5. X-Ray diffractogram (XRD) (a) and Infrared spectrum (FTIR) (b) of geopolymer pastes. 

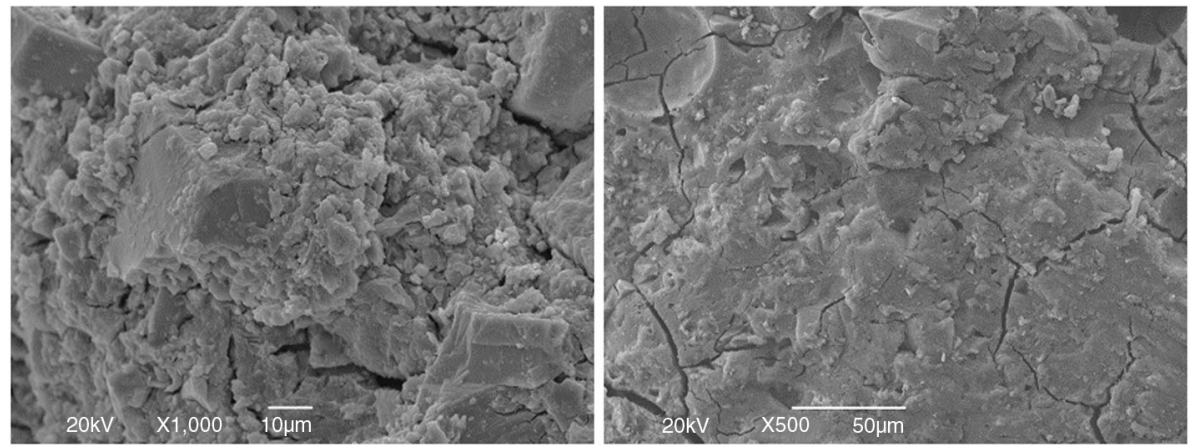

FIGURE 6. Microstructure of geopolymer pastes (Left; NP) (Right; NP+GBFS).

which can be associated with the vibrations of asymmetrical tension of the $\mathrm{O}-\mathrm{C}-\mathrm{O}$ bond of carbonates (calcite) that are originally present in GBFS and also with the presence of sodium bicarbonate, which could be caused by the phenomenon of atmospheric carbonation of the samples $(29,30)$.

Figure 6 shows the SEM micrographs obtained for each studied system. As observed, the binary systems with added GBFS show a more homogeneous and denser structure in comparison with the simple systems, where still non-dissolved and non-reacted pozzolan particles can be observed because of their high degree of crystallinity (XRD). These particles are immersed in the geopolymer phase. The presence of GBFS in the binary system increases the proportion of the amorphous phase in the blend, and therefore, the dissolution phenomenon and production of geopolymer gels are favoured; the observed cracks are attributed to retraction phenomena.

\section{CONCLUSIONS}

The low reactivity of the natural pozzolan used in this study, which is reflected by its semicrystalline nature and low $\mathrm{CaO}$ and soluble $\mathrm{Al}_{2} \mathrm{O}_{3}$ contents, affected the strengthening of simple systems with alkaline activation, which only achieved a strength of $12.96 \mathrm{MPa}$ after 28 days of curing at ambient temperature. At this age, the alkaline-activated pastes contained non-reacted NP particles immersed in the geopolymer gel.

The addition of granulated blast furnace slag to the volcanic pozzolan improved the silica to amorphous alumina ratio in the blend and favoured the dissolution and formation of the geopolymer gel, which increased the compressive strength and decreased the setting time. Thus, $30 \%$ of GBFS provided strength values of up to $48.11 \mathrm{MPa}$ after 28 days of curing at ambient temperature $\left(25^{\circ} \mathrm{C}\right)$ when the $\mathrm{SiO}_{2} / \mathrm{Al}_{2} \mathrm{O}_{3}$ ratio was 6.5. This increase in strength is in accordance with the increase in the total heat of reaction and the reduction of the initial and final setting times of the simple system (NP) of up to $143 \%$ and $87 \%$, respectively. This result demonstrates the viability of producing binary geopolymers $(\mathrm{NP}+\mathrm{GBFS})$ at ambient temperature from a blend of granulated blast furnace slag and volcanic pozzolans.

\section{ACKNOWLEDGEMENTS}

The authors, who are members of the Composite Materials Group (Grupo de Materiales Compuestos - GMC) and the Centre of Excellence in New Materials (Centro de Excelencia en Nuevos Materiales CENM) thank to Universidad del Valle (Colombia), Department of Science, Technology and Innovation, Colciencias and the private company Argos S.A. for the support received during the "PUZOGEOH" project (Colciencias-Argos) contract No. 0484-2013. R. Robayo thanks to Colciencias for the support received under project No. 617 of 2013 for their doctorate training.

\section{REFERENCES}

1. Pacheco-Torgal, F.; Castro-Gomez, J.; Jalali, S. (2008) Alkaliactivated binders: A review Part 1 . Historical background, terminology, reaction mechanisms and hydration products. Constr. Build. Mater. 22. 1305-1314. http://dx.doi.org/ 10.1016/j.conbuildmat.2007.10.015.

2. Komnitsas, K.; Zaharaki, D. (2007) Geopolymerisation: A review and prospects for the minerals industry. Mater. Eng. 20, 1261-1277. http://dx.doi.org/10.1016/j.mineng. 2007.07 .011

3. Majidi, B. (2009) Geopolymer technology, from fundamentals to advanced applications: a review Mater. Tech. 24 [2], 79-87. http://dx.doi.org/10.1179/175355509X449355.

4. Davidovits, J. (2013) Geopolymer Cement. A review. Geopolymer Institute, Technical papers 21, 1-11.

5. Provis, L.; Lukey, G.; Van Deventer, J. (2005) Reviews: Do geopolymers actually contain nanocrystalline zeolites? A re-examination of existing results. Chem. Mater. 17, 3075-3085. http://dx.doi.org/10.1021/cm050230i.

6. Palomo, A.; Krivenko, P.; Garcia-Lodeiro, I.; Kavalerova, E.; Maltseva, O.; Fernandez-Jimenez, A. (2014) A review on alkaline activation: new analytical perspectives. Mater. Construcc. 64 [315], 1-24. http://dx.doi.org/10.3989/mc.2014.00314.

7. Lizcano, A.; Herrera, M.; Santamarina, J. (2006) Suelos derivados de cenizas volcánicas en Colombia. Rev. Int. de desastres naturales, accidentes e infraestructura civil 6 [2], $167-197$ 
8. Lemougna, P.; Melo, U.F.; Delplancke, M.P.; Rahier H. (2014) Influence of the chemical and mineralogical composition on the reactivity of volcanic ashes during alkali activation. Ceram. Inter. 40, 811-820. http://dx.doi.org/ 10.1016/j.ceramint.2013.06.072.

9. Tchakoute, H.K.; Elimbi, A.; Yanne, E.; Djangang, C.N (2013) Utilization of volcanic ashes for the production of Geopolymers cured at ambient temperature. Cem. Concr. Compos. 38, 75-81. http://dx.doi.org/10.1016/j.cemconcomp. 2013.03.010

10. Bondar, D.; Lynsdale, C.J.; Milestone, N.B.; Hassani, N.; Ramezanianpour, A.A. (2011) Effect of heat treatment on reactivity-strength of alkali-activated natural pozzolans. Constr. Build. Mater. 25, 4065-4071. http://dx.doi.org/ 10.1016/j.conbuildmat.2011.04.044.

11. Kani, E.N.; Allahverdi, A. (2009a) Effect of chemical composition on basic engineering properties of inorganic polymeric binder based on natural pozzolan. Ceramics-Silikaty 53 [3], 195-204

12. Kani, E.N.; Allahverdi, A. (2009b) Effects of curing time and temperature on strength development of inorganic polymeric binder based on natural pozzolan. J. Mater. Sci. 44 , 3088-3097. http://dx.doi.org/10.1007/s10853-009-3411-1.

13. Allahverdi, A.; Kani, N.; Yazdanipour, M. (2011) Effects of blast-furnace slag on natural pozzolan-based geopolymer cement. Ceramics-Silikáty 55 [1], 68-78.

14. Djobo, J.N.Y.; Tchadjié, L.N.; Tchakoute, H.K.; Kenne, B.B.D., Elimbi, A.; Njopwouo, D. (2014) Synthesis of geopolymer composites from a mixture of volcanic scoria and metakaolin. Journal of Asian Ceramic Societies 2 [4], 387-398. http://dx.doi.org/10.1016/j.jascer.2014.08.003.

15. Rodríguez, E.; Bernal, S.; Mejía de Gutiérrez, R.; Puertas, F. (2008) Hormigón alternativo basado en escorias activadas alcalinamente. Mater. Construcc. 58 [291], 53-57. http:// dx.doi.org/10.3989/mc.2008.v58.i291.104.

16. Li, Ch.; Sun, H.; Li, L. (2010) A review: The comparison between alkali-activated slag $(\mathrm{Si}+\mathrm{Ca})$ and metakaolin ( $\mathrm{Si}+\mathrm{Al})$ cements. Cem. Concr. Res. 40, 1341-1349. http:// dx.doi.org/10.1016/j.cemconres.2010.03.020.

17. Bernal, S.A.; Mejía de Gutierrez, R.; Pedraza, A., Provis, J.L.; Rodriguez, E.D.; Delvasto, S. (2011) Effect of binder content on the performance of alkali-activated slag concretes. Cem. Concr. Res. 41, 1-8. http://dx.doi.org/10.1016/j. cemconres.2010.08.017.

18. Allahverdi, A.; Saffari M. (2011) Imparting cementing properties to natural pozzolan with a solid compound chemical activator. $4^{\text {th }}$ International Conference Non-Traditional Cement \& Concrete, 565-572.

19. Kani, N.; Allahverdi, A.; Provis, J.L. (2012) Efflorescence control in geopolymer binders based on natural pozzolan.
Cem. Concr. Compos. 34, 25-33. http://dx.doi.org/10.1016/j. cemconcomp.2011.07.007.

20. Tironi, A.; Trezza, M.; Irassar, E.; Scian, A. (2012) Activación térmica de bentonitas para su utilización como puzolanas. Revista de la Construcción 11 [1], 44-53. http://dx.doi.org/ 10.4067/S0718-915X2012000100005.

21. Davidovits, J. (2011) Application of Ca-based geopolymer with blast furnace slag, a review. $2^{\text {nd }}$ International Slag Valorisation Symposium, 33-49.

22. Zhang, Z.; Wang, H.; Zhu, Y.; Reid, A.; Provis, J.; Bullen, F. (2014) Using fly ash to partially substitute metakaolin in geopolymer synthesis. App. Clay Sci. 88-89, 194-201. http://dx.doi.org/10.1016/j.clay.2013.12.025.

23. Allahverdi, A.; Mehrpour, K.; Kani, E.N. (2008) Investigating the possibility of utilizing pumice-type natural pozzolan in production of Geopolymer cement. Ceramics-Silikaty 52 [1], $16-23$.

24. Xu, H.; Gong, W.; Syltebo, L.; Lutze, W.; Pegg, I.L. (2014) DuraLith geopolymer waste form for Hanford secondary waste: Correlating setting behavior to hydration heat evolution. J. Hazardous Mater. 278, 34-39. http://dx.doi. org/10.1016/j.jhazmat.2014.05.070.

25. Fernández - Jiménez, A ; Puertas, F (1997) Influence of the activator concentration on the kinetics of the alkaline activation process of a blast furnace slag. Mater. Construcc. 47 [246], 31-42. http://dx.doi.org/10.3989/mc.1997.v47.i246.505.

26. Snellings, R.; Mertens, G.; Elsen, J. (2010) Calorimetric evolution of the early pozzolanic reaction of natural zeolites. $J$. Therm. Anal. Calorim. 101,97-105. http://dx.doi.org/10.1007/ s10973-009-0449-x.

27. Rahhal, V.; Talero, R. (2010) Fast physics-chemical and calorimetric characterization of natural pozzolans and other aspects. J. Therm. Anal. Calorim. 99, 479-486. http:// dx.doi.org/10.1007/s10973-009-0016-5.

28. Lemougna, P.; MacKenzie, J.D.; Melo, U.F. (2011) Synthesis and thermal properties of inorganic polymers (geopolymers) for structural and refractory applications from volcanic ash. Ceram. Inter. 37, 3011-3018. http://dx.doi.org/10.1016/j. ceramint.2011.05.002.

29. Puertas, F; Torres-Carrasco, M. (2014) Use of glass waste as an activator in the preparation of alkali-activated slag. Mechanical strength and paste characterization. Cem. Concr. Res. 57, 95-104. http://dx.doi.org/10.1016/j.cemconres. 2013.12.005.

30. Tchakoute, H.K.; Elimbi, A.; Mbey, J.A.; Ngally, C.J.; Njopwouo, D. (2012) The effect of adding alumina-oxide to metakaolin and volcanic ash on geopolymer products: A comparative study. Constr. Build. Mater. 35, 960-969. http://dx.doi.org/10.1016/j.conbuildmat.2012.04.023. 